Western University

Scholarship@Western

Aboriginal Policy Research Consortium International (APRCi)

$11-2011$

Empowering Indigenous peoples' biocultural diversity through World Heritage cultural landscapes: a case study from the Australian humid tropical forests

Rosemary Hill

Leanne C. Cullen-Unsworth

Leah D. Talbot

Susan McIntyre-Tamwoy

Follow this and additional works at: https://ir.lib.uwo.ca/aprci

Part of the Environmental Policy Commons

Citation of this paper:

Hill, Rosemary; Cullen-Unsworth, Leanne C.; Talbot, Leah D.; and McIntyre-Tamwoy, Susan, "Empowering Indigenous peoples' biocultural diversity through World Heritage cultural landscapes: a case study from the Australian humid tropical forests" (2011).

Aboriginal Policy Research Consortium International (APRCi). 398.

https://ir.lib.uwo.ca/aprci/398 
This article was downloaded by: [University of Western Ontario]

On: 10 December 2012, At: 07:58

Publisher: Routledge

Informa Ltd Registered in England and Wales Registered Number: 1072954 Registered

office: Mortimer House, 37-41 Mortimer Street, London W1T 3J H, UK

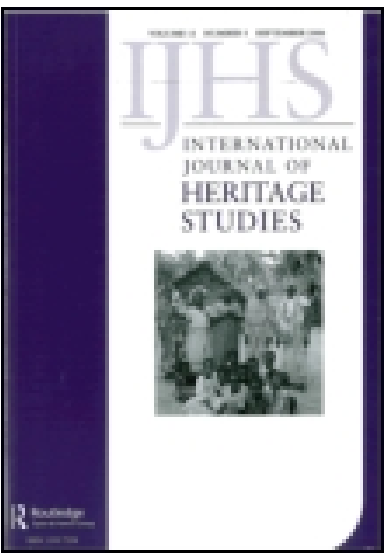

\section{International J ournal of Heritage Studies}

Publication details, including instructions for authors and subscription information:

http:// www.tandfonline.com/loi/ rjhs20

\section{Empowering Indigenous peoples'} biocultural diversity through World Heritage cultural landscapes: a case study from the Australian humid tropical forests

Rosemary Hill ${ }^{a}$, Leanne C. Cullen-Unsworth ${ }^{b}$, Leah D. Talbot ${ }^{c} \&$ Susan McIntyre-Tamwoy ${ }^{d}$

${ }^{a}$ CSIRO Ecosystem Sciences and School of Earth and Environmental Sciences, J ames Cook University, Cairns Queensland, Australia

b Sustainable Places Research Institute, Cardiff University, UK ${ }^{c}$ Australian Conservation Foundation, Cairns, Queensland, Australia

d School of Arts and Social Sciences, J ames Cook University, Cairns, Queensland, Australia Version of record first published: 08 Dec 2011.

To cite this article: Rosemary Hill, Leanne C. Cullen-Unsworth, Leah D. Talbot \& Susan McIntyreTamwoy (2011): Empowering Indigenous peoples' biocultural diversity through World Heritage cultural landscapes: a case study from the Australian humid tropical forests, International J ournal of Heritage Studies, 17:6, 571-591

To link to this article: http:// dx.doi.org/ 10.1080/ 13527258.2011.618252

\section{PLEASE SCROLL DOWN FOR ARTICLE}

Full terms and conditions of use: http://www.tandfonline.com/page/terms-andconditions

This article may be used for research, teaching, and private study purposes. Any substantial or systematic reproduction, redistribution, reselling, loan, sub-licensing, systematic supply, or distribution in any form to anyone is expressly forbidden. 
The publisher does not give any warranty express or implied or make any representation that the contents will be complete or accurate or up to date. The accuracy of any instructions, formulae, and drug doses should be independently verified with primary sources. The publisher shall not be liable for any loss, actions, claims, proceedings, demand, or costs or damages whatsoever or howsoever caused arising directly or indirectly in connection with or arising out of the use of this material. 


\title{
Empowering Indigenous peoples' biocultural diversity through World Heritage cultural landscapes: a case study from the Australian humid tropical forests
}

\author{
Rosemary Hill ${ }^{\mathrm{a} *}$, Leanne C. Cullen-Unsworth ${ }^{\mathrm{b}}$, Leah D. Talbot ${ }^{\mathrm{c}}$ and Susan \\ McIntyre-Tamwoy ${ }^{\mathrm{d}}$ \\ ${ }^{a}$ CSIRO Ecosystem Sciences and School of Earth and Environmental Sciences, James \\ Cook University, Cairns Queensland, Australia; ${ }^{b}$ Sustainable Places Research Institute, \\ Cardiff University, UK; ' Australian Conservation Foundation, Cairns, Queensland, \\ Australia; ${ }^{d}$ School of Arts and Social Sciences, James Cook University, Cairns, Queensland, \\ Australia
}

(Received 14 May 2010; final version received 15 February 2011)

\begin{abstract}
Australian humid tropical forests have been recognised as globally significant natural landscapes through world heritage listing since 1988. Aboriginal people have occupied these forests and shaped the biodiversity for at least 8000 years. The Wet Tropics Regional Agreement in 2005 committed governments and the region's Rainforest Aboriginal peoples to work together for recognition of the Aboriginal cultural heritage associated with these forests. The resultant heritage nomination process empowered community efforts to reverse the loss of biocultural diversity. The conditions that enabled this empowerment included: Rainforest Aboriginal peoples' governance of the process; their shaping of the heritage discourse to incorporate biocultural diversity; and their control of interaction with their knowledge systems to identify the links that have created the region's biocultural diversity. We recommend further investigation of theory and practice in Indigenous governance of international heritage designations as a means to empower community efforts to reverse global biocultural diversity loss.
\end{abstract}

Keywords: biocultural diversity; Aboriginal; Indigenous; rainforest; heritage

\section{Introduction}

Cultural landscapes represent the interface between nature and culture and exist due to the complex interactions between people and the environment over time (Rössler 2005). Since 1992, the World Heritage Convention has provided for inclusion of cultural landscapes that are of outstanding universal value ${ }^{1}$ within the World Heritage list (Aplin 2007). Adoption of the World Heritage Cultural Landscape (WHCL) designation marked a new approach to traditional management systems and customary law, recognising these as appropriate forms of protection for globally significant heritage. The initiative clearly had the potential to empower the transmission of Indigenous $^{2}$ cultural diversity, traditional knowledge and biocultural resources to future generations (Rössler 2004). Indigenous peoples at Tongariro National Park (New Zealand) and Uluru-Kata Tjuta (Australia), the first two WHCLs designated

*Corresponding author. Email: ro.hill@csiro.au 
for associations with living Indigenous cultures, used the recognition to empower some of their aspirations (Lennon 2006). Anangu people developed an information management system that facilitated better integration of their customary law (Tjukurpa), further empowering their roles in joint management with the national government's agency, Parks Australia, at Uluru-Kata Tjuta (Lennon 2006, Ross et al. 2009). The paramount Indigenous leader of Tongariro, Tumu Te Heuheu, became Chairman of the World Heritage Committee, and facilitated dialogue that empowered international understanding of customary law (Metge 2008). However, WHCL processes have not universally empowered Indigenous and local peoples. Listing of the rice terraces in the Philippines' Cordilleras as a WHCL has not enabled local people to obtain the financial and institutional support necessary to continue their labour-intensive traditional maintenance practices (Villalón 2005). Rainforest Aboriginal people in the Australian Wet Tropics World Heritage Area (WTWHA), currently only recognised as globally significant for its natural values ${ }^{3}$ (Figure 1), are pursuing listing as a Cultural Landscape to strengthen their Indigenous culture, rights and interests. The contribution of this initiative to theory and practice regarding the capacity of international designations to empower biocultural diversity forms the focus of the co-research reported in this paper.

Biocultural diversity, defined as the total variety exhibited by the world's natural and cultural systems, denotes three concepts: (1) diversity of life includes human cultures and languages; (2) links exist between biodiversity and cultural diversity; and (3) these links have developed over time through mutual adaptation and possibly co-evolution (Loh and Harmon 2005, Maffi 2007). Interrogations of global patterns of biocultural diversity have shown that correlations exist between areas of high biodiversity and high cultural diversity - and that the current species extinction crisis is paralleled by a related extinction crisis affecting linguistic and cultural diversity (Loh and Harmon 2005, Maffi 2005, Bradshaw et al. 2009). The notion of WHCL closely aligns with concepts of biocultural diversity, explicitly recognising the relationship between biological and cultural diversity, and between tangible and intangible cultural heritage (Rössler 2005, ICOMOS 2009). WHCL designation acknowledges the role of people in creating biodiverse landscapes and provides a mechanism for explicit recognition of that role.

The process of world heritage listing, however, can be mysterious and alienating to local people and Traditional Owners (TOs) ${ }^{4}$ creating high potential for misunderstanding and hostility (Sullivan 2004). Community-based approaches to heritage nomination, listing and management are gaining recognition as key to overcoming these risks of alienation and conflict (McIntyre-Tamwoy 2004, Kato 2006, Greer 2010). However, world heritage nomination is still largely top-down, without clearly established means of enabling local ownership - most focus has been on engaging the community after the site is listed (Sullivan 2004, Cullen et al. 2008). These engagement processes continue to be seriously challenged by fundamental critiques that conservation management undermines local peoples' rights and interests and requires re-modelling from the ground up, involving local governance, networks and linkages across various institutions (Berkes 2007, Smith 2007). In this context, our research, which presents and interrogates an Indigenous-driven heritage nomination process, is timely and useful.

We write this paper as a team of Indigenous and non-Indigenous scholars and practitioners (within a university, a government and a non-governmental organisation) involved in supporting processes to achieve recognition of Indigenous peoples' 


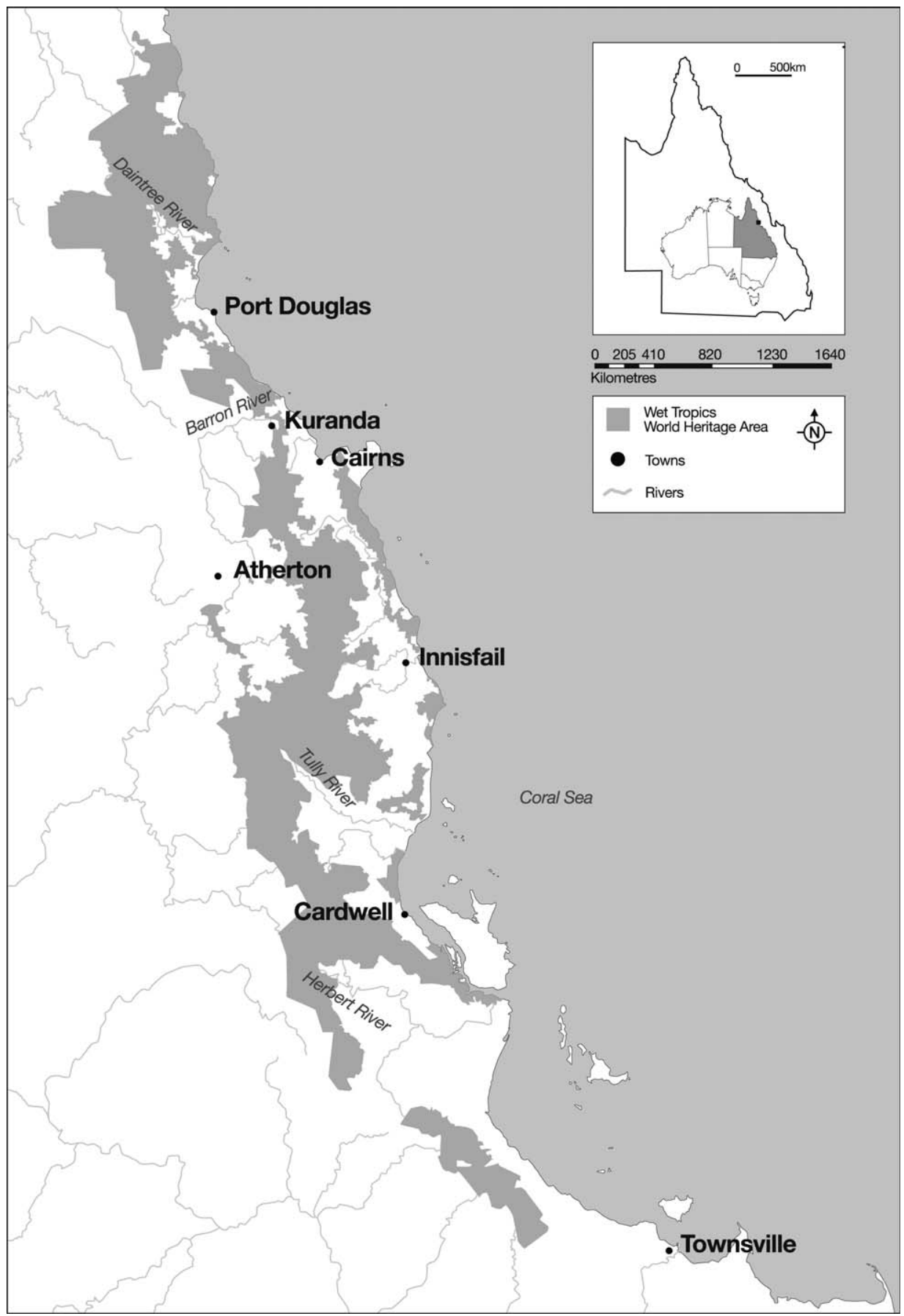

Figure 1. Wet Tropics World Heritage Area. 
biocultural diversity within the WTWHA. The paper investigates whether the heritage nomination process towards re-listing the WTWHA as a cultural landscape has empowered community efforts to reverse the loss of biocultural diversity.

\section{Biocultural diversity and Indigenous governance: key issues and definitions}

The concept of biocultural diversity is gaining recognition; a recent global survey highlighted linkages between cultural practices and biodiversity in 45 case studies encompassing six continents (Maffi and Woodley 2010). However, the characteristics of linkages between culture and biodiversity are not yet well elucidated, and clear conceptual frameworks for assessment remain elusive (Persic and Martin 2008). Where correlations exist between cultural and biological diversity, studies have not yet identified whether this has arisen from co-evolution, asymmetric causation (e.g. human-modified landscapes) or by other factors that affect both (e.g. division of habitat types and socio-ethnic territories by mountains, islands or climatic conditions) (Zent 2009).

Furthermore, culture and linkage to place are both contested concepts (Silverman 2011). The ideal of distinct local communities linked to their local environment through homeostatic feedback loops has not withstood scholarly scrutiny: communities are now recognised as contingent and dynamic, resulting from interactions between social actors at multiple scales, generating diversity within communities that affects heritage values and management (Leach et al. 1999, Chirikure et al. 2010, Singh et al. 2010). Indigenous culture itself is best understood as a dynamic process of transcultural exchange with critical and complex processes of intercultural hybridisation in which Indigenous and local peoples are key actors and drivers of change (Cocks 2006). A clear means of recognising these tensions is required to ensure that research into 'biocultural diversity' does not reinvigorate a colonising scholarship or reinforce networks of power relations that control Indigenous interests and futures for the purposes of others (Hemming and Rigney 2010). We situate our research within an adaptive governance theoretical framework, to recognise the multiple regimes of credibility pertaining to the different contexts in which Indigenous people, scientists, practitioners, decision-makers, community members and other actors work (Persic and Martin 2008).

We acknowledge concepts of multi-scalar interaction, complexity, uncertainty, dynamism and evolution that respond to the contested definitions of culture and nature discussed above are encapsulated in the theory of adaptive co-management (Armitage et al. 2007, Hill et al. 2010). Adaptive governance builds on this by adding the dimension of accounting for Indigenous peoples' explicit claims to a distinct and separate political status (United Nations 2008, Hill and Williams 2009). Indigenous governance encapsulates the processes by which Indigenous people make decisions and share power, define their culture, their biocultural diversity and means for cultural sustainability (Folke et al. 2005, Sveiby 2009, Hemming and Rigney 2010). Indigenous governance played a key role in the conduct of the co-research outlined in this paper, and was integral to the nomination process interrogated.

\section{Wet tropics context: from a natural to a biocultural landscape}

During the period of territorial acquisition and settlement of Australia by the British, the wet tropical rainforests were viewed by the nascent nation-state primarily as a barrier to progress. By the 1930 s, following extensive clearing for agriculture, the rain- 
forest came to be valued as an important source of timber resources (Valentine and Hill 2008). The inscription of the Wet Tropics onto the World Heritage List in 1988 for its natural values signalled a shift towards valuing the rainforests as a natural landscape of global significance. The era of timber extraction ended, although unprecedented rates of population growth and urbanisation continue to drive contestation about environmental, economic and cultural values, and the relative roles of local, state and national governments in its management (Stork et al. 2008). At the time of inscription, Rainforest Aboriginal groups were divided between those who supported the listing because of links between cultural maintenance and rainforest protection, and those who opposed it as a limitation on their rights (Horsfall and Fuary 1988).

Since 1988, Rainforest Aboriginal peoples have engaged in a struggle for recognition of their roles in the WTWHA (Pannell 2008a). This struggle has been promulgated through three parallel strategies: seeking recognition of rights, involvement in environmental management roles and legitimation of cultural values. Figure 2 illustrates how three strategies together aim to achieve reconciliation between the Aboriginal and settler societies. The ultimate goal is to transform perception and management

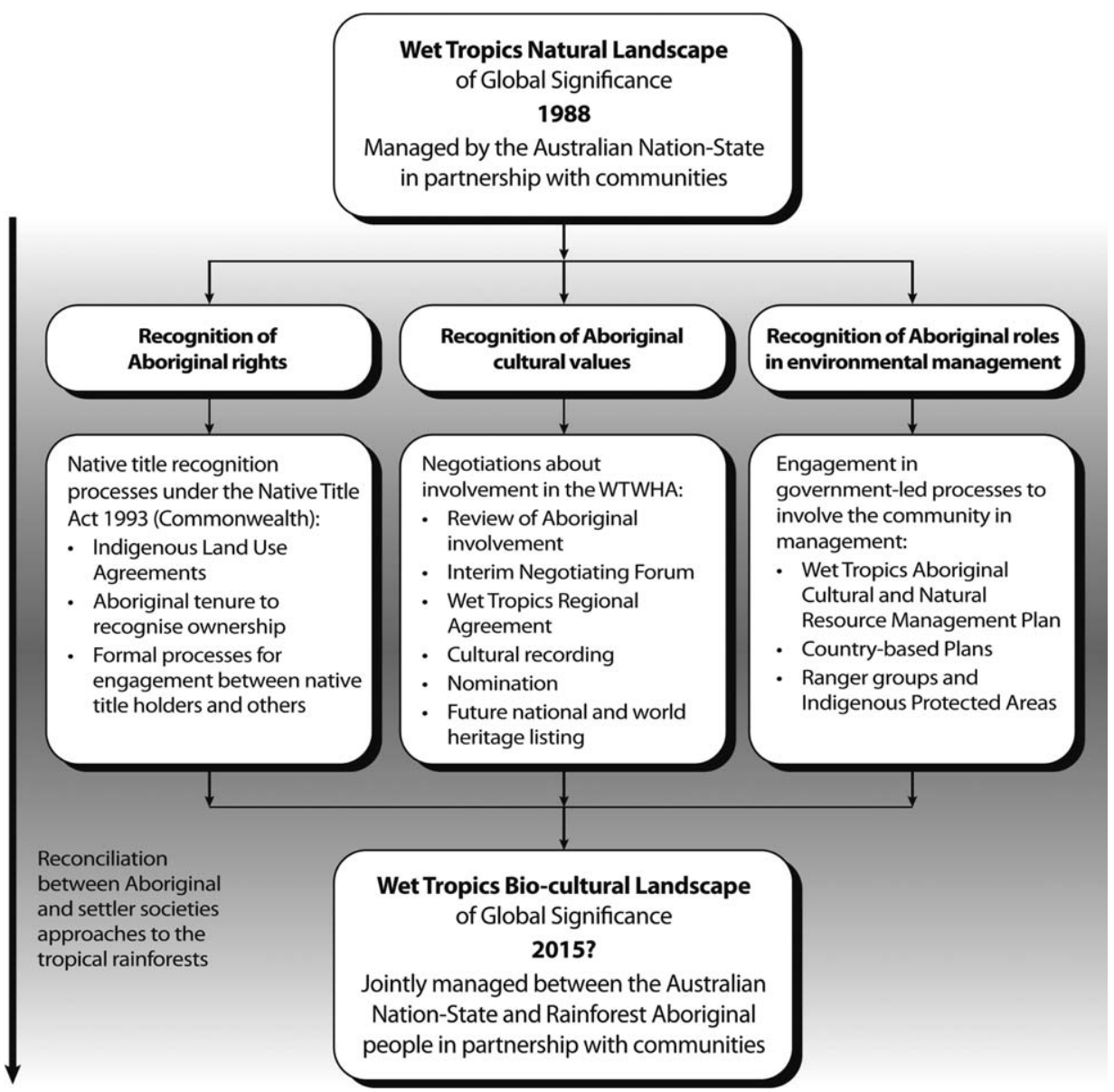

Figure 2. Parallel processes of recognition of rights, cultural values and roles in environmental management. The ultimate goal is to transform perception and management of a natural landscape into perception and management of a bio-cultural landscape. 
of the WTWHA as a globally significant natural landscape into its perception and management as a globally significant biocultural landscape. The first strategy, rightsrecognition, has been pursued through the Australian native title legal system, which has resulted in formal Indigenous Land Use Agreements under the Native Title Act 1993 (Commonwealth) (Hill 2006). The second strategy of seeking roles in management has focused on the Australian government's Natural Resource Management (NRM) programmes, using initiatives including Aboriginal Management Plans, Ranger groups and Indigenous Protected Areas to propel the adoption of Aboriginal-driven environmental management (Pannell 2008b). The third strategy, recognition of cultural values, has been pursued through entering into negotiations with the Australian and Queensland governments about involvement in the WTWHA. A formal review of management arrangements put in place at the time of listing led to the establishment of an Interim Negotiating Forum. This included representatives of the 18 Traditional Owner groups recognised in the WTWHA, and both Australian and Queensland governments (Lawson 1998, Cochrane 2003). A Regional Agreement was finalised in 2005, committing the Australian and Queensland governments to work in partnership with these 18 groups, generically termed Rainforest Aboriginal peoples, including through seeking cultural heritage listing.

Rainforest Aboriginal peoples established the Aboriginal Rainforest Council (ARC) in March 2003 as an independent decision-making organisation to represent their strategic interests in the WTWHA and subsequently the Regional Agreement. The ARC constituted a new regional element within a contemporary multi-level Indigenous governance system with nested governance arrangements, including at sub-regional (e.g. Girringun Aboriginal Corporation), local (e.g. Djabugay Tribal Council) and extended family scales (e.g. Bana Yarralji Bubu Incorporated). The Regional Agreement recognised the ARC as the entity charged with establishing and maintaining the authority to represent the views of Rainforest Aboriginal people regarding management of the WTWHA (WTRA 2005).

However, the Aboriginal Rainforest Council as a formal incorporated organisation no longer exists. It was disbanded in 2008 following problems with administration and funding. Rainforest Aboriginal peoples are now developing alternative structures to provide the necessary coordination of their multi-level governance responsibilities. Ongoing Indigenous governance responsibilities are exercised without a formal organisation, and ensuring adequately resourced arrangements for their coordination at the regional scale remains a challenge. The slow response by governments to these resourcing needs is testimony to the ongoing marginalisation of Indigenous peoples from the NRM arrangements of the Australian nation-state (Hill and Williams 2009). We return to a consideration of the impact of this issue on the empowerment of community efforts to reverse biocultural diversity loss in the conclusion.

\section{Co-research methods}

Our co-research approach occurred within the processes of nomination of the Aboriginal cultural values of the wet tropics for heritage listing. In 2006, the ARC and Girringun Aboriginal Corporation (Girringun), in partnership with Terrain NRM, a non-governmental organisation with a focus on natural resource management, obtained funding for a cultural heritage mapping project. This project had two goals: (1) to enable local TO groups to record, store and apply their cultural heritage information in relation to the management of their traditional country; and 
(2) to prepare a document to support nomination of the wet tropics as a cultural landscape for national and, subsequently, world heritage listing (Hill and Williams 2009). A co-research framework was developed iteratively with the Rainforest Aboriginal governance arrangements.

The three initial partners to the cultural mapping project-ARC, Girringun and Terrain-identified that further expertise was required to ensure preparation of the heritage nomination document. Relevant potential co-researchers were invited from James Cook University (JCU) and the Commonwealth Scientific and Industrial Research Organisation (CSIRO), supported by funding through the Australian Government's Marine and Tropical Science Research Facility. Participation of the proposed co-researchers was approved at a meeting of the 18 Traditional Owner groups hosted by ARC, whereby JCU and CSIRO became project partners. The core coresearch team included four scientists working closely with six senior TOs, supported by a coordinator, and a heritage officer from the Wet Tropics Management Authority (WTMA), the government agency responsible for the WTWHA. This approach recognises that the co-generation of knowledge by Indigenous peoples and scientists, through research, can be used to build knowledge with credibility in both domains (Cullen et al. 2008, Maclean and Cullen 2009). The co-research team met many times during the preparation of the nomination, which occurred between July 2006 and December 2007. Subsequent interrogation and analysis to consider the question of empowerment of community efforts for biocultural diversity conservation through the heritage nomination process was undertaken by four members of the original team, in consultation with TO groups through their multi-level governance structures.

Data sources included the nomination document itself, documents compiled to prepare the nomination (academic and popular articles and books, policies, plans, media releases, project proposals and annual reports), minutes of meetings, digital videodisc (DVD) recordings, and workshop and consultation reports. Analysis of the data followed qualitative techniques of theme identification, grouping and matrix formulation (Robinson 1998). We strengthened the validity of our analysis through application of frameworks drawn from comparable international practice. Biocultural Community Protocols (BCP) provided the framework for analysis of how the heritage listing process had empowered community efforts (UNEP 2009). The UNESCO list (Persic and Martin 2008) of 'areas of interdependence between biological and cultural diversity' provided the framework for analysis of how the nomination content had empowered the inclusion of evidence about biocultural diversity.

\section{Preparing the heritage nomination}

Our co-research identifies that the heritage nomination process empowered community efforts to reverse the loss of biocultural diversity. The conditions that enabled this empowerment included: (1) Rainforest Aboriginal peoples' governance of the process; (2) their shaping of the heritage discourse to incorporate biocultural diversity; and (3) their control of interactions with their knowledge systems to identify the links that have created the region's biocultural diversity.

\section{Empowerment of community efforts through Rainforest Aboriginal governance}

The heritage nomination project worked from the principle that Traditional Owners should take control of knowledge production concerning their culture. Through their recording activities, TOs are in a better position to ensure that co-management of 
the WTWHA effectively addresses their cultural values, knowledge and practices. The ARC appointed an Indigenous Intellectual Property Sub-committee (IPSC) to guide the nomination process, reporting back to TOs through meetings (hosted by ARC) that included representatives from all 18 TO groups. A Memorandum of Understanding $(\mathrm{MoU})$ between the ARC and other organisations ensured Indigenous governance of the process. Figure 3 was developed by ARC (2006) as part of the $\mathrm{MoU}$, and illustrates the complex arrangements established to ensure that Rainforest Aboriginal peoples were the decision-makers and governed the process. The technical and administrative complexity of heritage processes required engagement of many groups. Government organisations with an advisory role, were clearly part of a 'Technical Group', which was led by the WTMA, whose officer provided ongoing support to the co-research team. Organisations that employed members of the coresearch team were identified as 'Project Partners'. TOs were clearly identified in both the 'top' decision-making role and the 'bottom' action role. These arrangements ensured multi-level empowerment of Rainforest Aboriginal people as both decision-makers and on-ground actors in the heritage nomination process

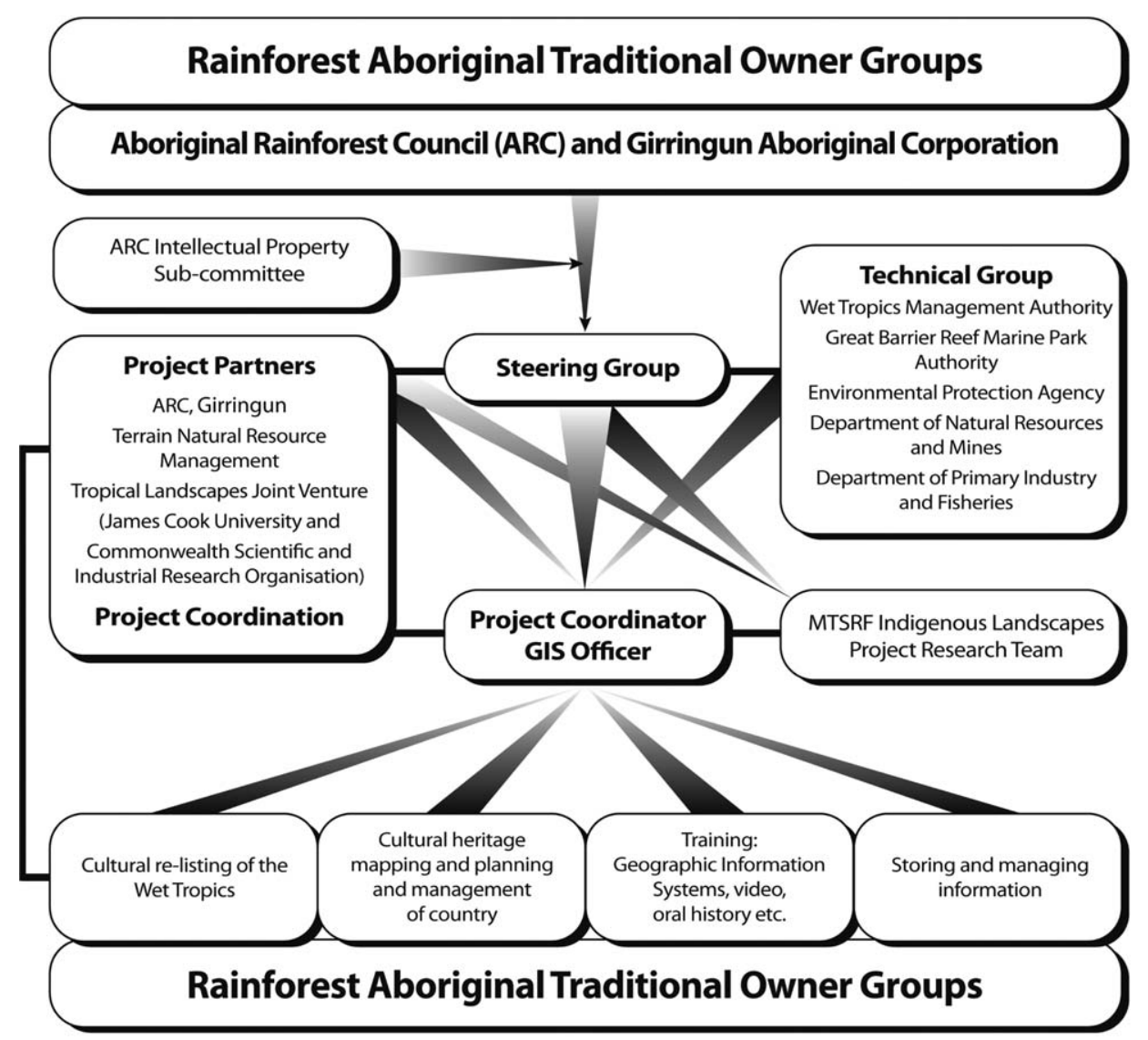

Figure 3. Rainforest Aboriginal governance arrangements for the heritage nomination process (ARC 2006). 


\section{Empowerment of community efforts through Rainforest Aboriginal heritage discourse}

The ARC IPSC began the heritage nomination process by examining documents previously prepared to scope out a potential nomination. They directed that the archaeological, anthropological and historical aspects be supplemented with a greater emphasis on living cultural traditions. A number of Elders made DVD recordings in which they explained the global significance of their living cultural traditions. They emphasised that this globally significant landscape had been created by their ancestral beings, was maintained by their ongoing connections, and therefore their culture was also globally significant. In effect, they argued that if the 'bio' aspect of a globally significant biocultural landscape was significant, then the 'cultural' part must also be. An Expert Panel was hosted during the Australian International Council on Monuments and Sites (ICOMOS) conference held in Cairns in August 2007 at which Rainforest Aboriginal people presented their draft 'statement of significance' to national and international cultural and natural heritage experts. The Expert Panel advised that the biocultural significance argument would not meet current heritage criteria. The Panel suggested the ARC focus on the uniqueness of Aboriginals' long occupation of rainforest, and associated innovative food processing and fire technologies, while including information about Aboriginal cultural connections. The Panel also emphasised the need for published material to support the claims. The DVDs would be useful illustrative material, but would not hold weight in the assessment of the nomination.

The members of the ARC made a decision to align the nomination document with this advice, but to include their DVD recordings, as well as substantial material explaining their understanding of the biocultural values of the WTWHA. The nomination document focused on the living cultural practices that have created and maintained the wet tropics landscape, and addressed current heritage criteria this amalgam produced a new Rainforest Aboriginal heritage discourse focused on biocultural diversity. The nomination was submitted in December 2007, and is currently being assessed by the Australian Government through the Australian Heritage Council, who recently announced that a decision is imminent.

\section{Empowerment of community efforts through Rainforest Aboriginal knowledge systems}

Empowerment occurred though the compilation of the heritage nomination document, led by Rainforest Aboriginal people. They explored and revealed the interactions between their culture and nature that have produced wet tropics biocultural diversity. In addition to preparation of the nomination document, the cultural heritage mapping project enabled local TO groups to record, store and apply their cultural heritage information. Through this process, Rainforest Aboriginal people gained access to resources that enabled them to spend time on their traditional country, recording traditional knowledge and language systems, and interacting with these landscapes through cultural management practices. The cultural recording process reinvigorated intergenerational transfer of knowledge, renewing respect by the younger generation for the role of the Elders. 


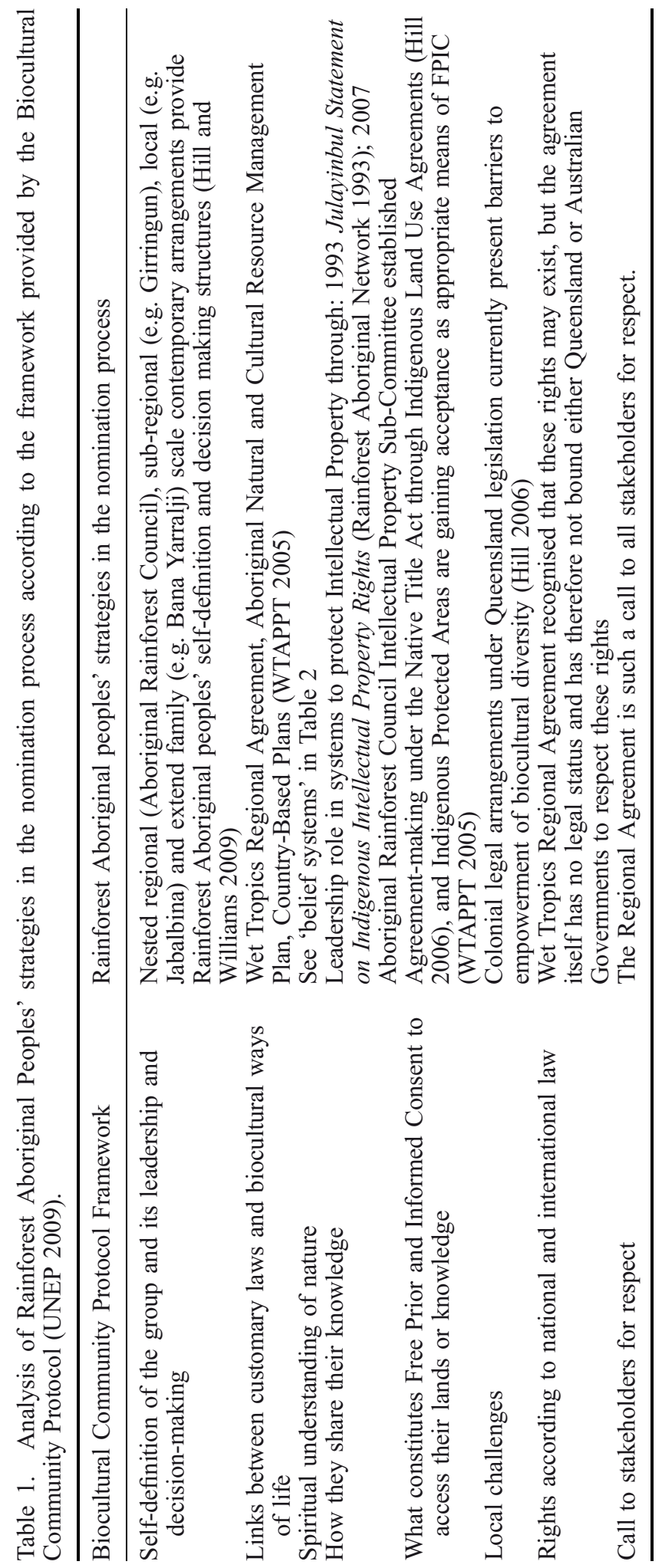




\section{Application of analytical frameworks from comparable international practice}

The Bio-cultural Community Protocols framework was applied to analyse the heritage listing process (UNEP 2009; Table 1). A BCP is a protocol that is developed through community consultation to outline core ecological, cultural and spiritual

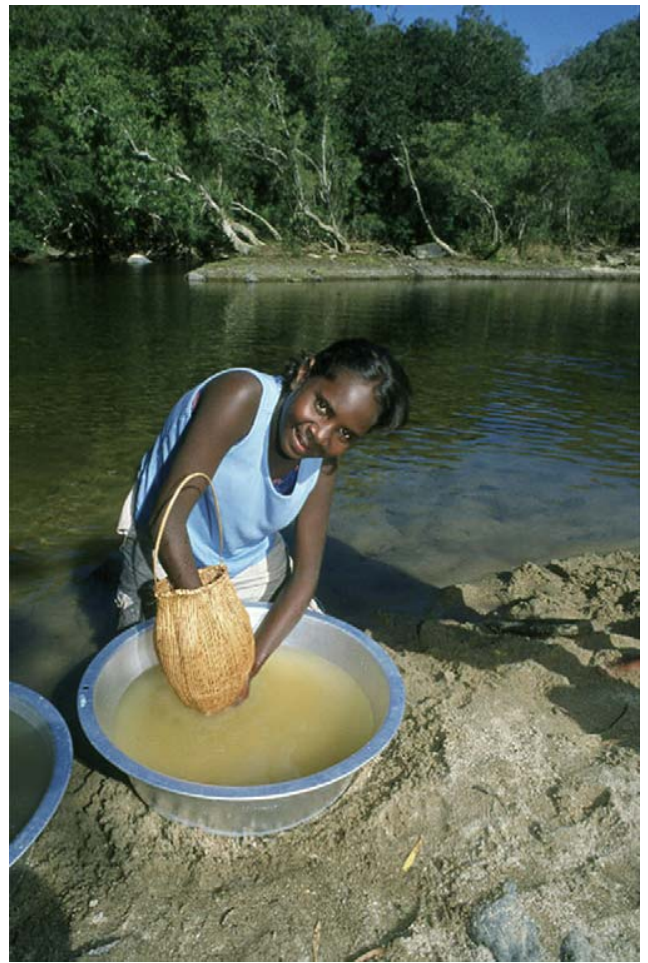

Photo 1. Telika Greenwall processing wukay, a traditional food, under instructions from Rainforest Aboriginal Elders. Photograph: S. Nowakowski. Reprinted with copyright permission from Eastern Kuku-Yalanji people.

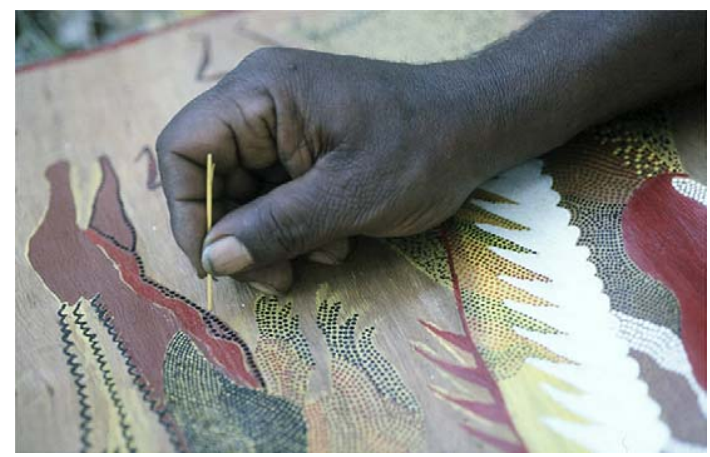

Photo 2. Cedric Friday painting crocodile and fish, important animals in Rainforest Aboriginal peoples' biocultural diversity. Photograph: S. Nowakowski. Reprinted with copyright permission from Eastern Kuku-Yalanji people. 


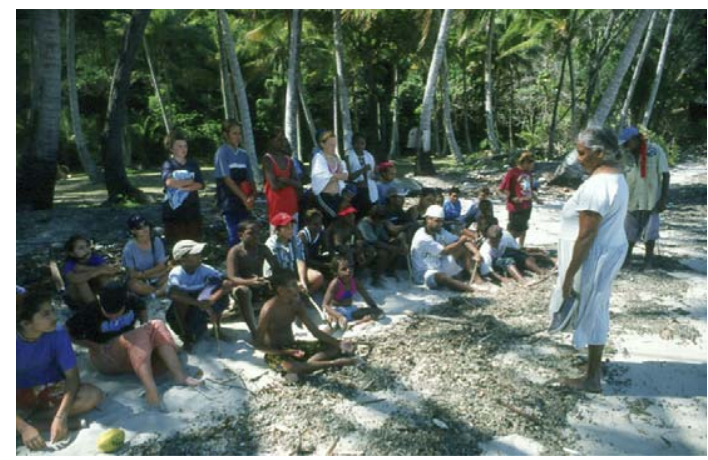

Photo 3. Rainforest Aboriginal Elder Agnes Burchill passing on cultural knowledge to the younger generation at Cape Kimberley, northern wet tropics. Photograph: S. Nowakowski. Reprinted with copyright permission from Eastern Kuku-Yalanji people.

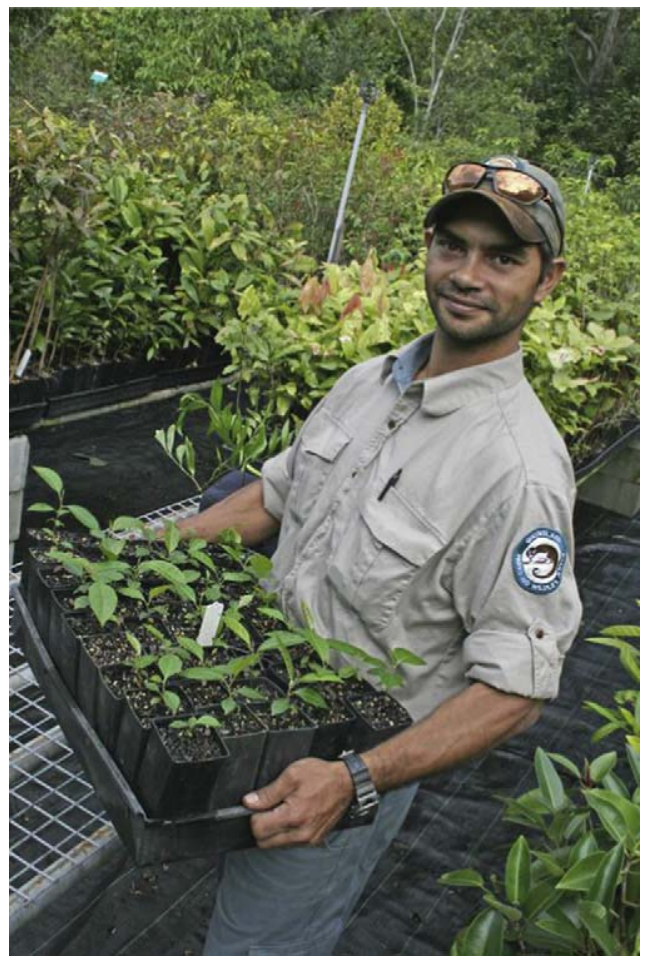

Photo 4. Darren Caulfield, a Rainforest Aboriginal Traditional Owner, involved in contemporary management of biocultural diversity. Photograph reprinted with copyright permission from the Wet Tropics Management Authority.

values and customary laws that relate to traditional knowledge and resources. The BCP establishes the basis for terms and conditions to regulate access to these resources and knowledge. Analysis of international applications has identified that BCPs that enable the community to empower its role in maintaining biocultural diversity address eight elements presented in Table 1: (1) self-definition of the 


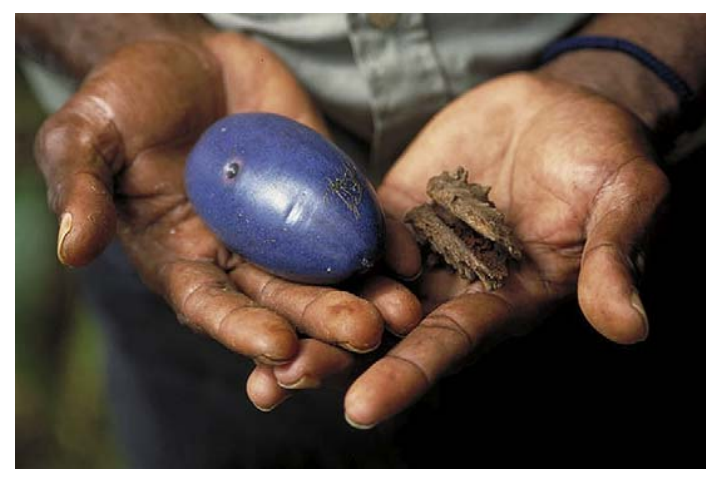

Photo 5. Cassowary plum (Cerbera floribunda K. Schum.), recognised by Rainforest Aboriginal people as a vital food source for cassowary. Photograph reprinted with copyright permission from the Wet Tropics Management Authority.

group and its decision-making; (2) links between customary laws and biocultural ways of life; (3) spiritual understanding of nature; (4) ways to share knowledge; (5) what constitutes Free Prior and Informed Consent; (6) local challenges; (7) rights according to national and international law; and (8) a call to stakeholders for success (UNEP 2009; Table 1). We analysed the processes underpinning this heritage nomination against the framework for BCPs from other international applications (Table 1). Rainforest Aboriginal peoples' three parallel strategies-pursuing recognition of rights, culture and management roles - ensured that all the elements were included. BCPs that contain all these elements have been found to be effective drivers of conservation and sustainable use of biodiversity in ways that support Indigenous livelihoods and traditional ways of life, confirming the importance of embedding the heritage nomination process in this wider set of activities (UNEP 2009).

The UNESCO framework of 'areas of interdependence between biological and cultural diversity' provided the basis for our analysis of nomination content (Persic and Martin 2008). Table 2 presents this framework of seven major categories, each with several sub-categories, that must be included to describe the multiple culturenature links underpinning biocultural diversity: (1) language and linguistic diversity; (2) material culture; (3) knowledge and technology; (4) modes of subsistence; (5) economic relations; (6) social relations; and (7) belief systems (Persic and Martin 2008; Table 2). We found that the nomination document provides insight into all the categories of linkages between nature and culture recognised in this global framework (Table 2). Rainforest Aboriginal peoples' exploration and revelation has therefore empowered an understanding that is likely to encapsulate the set of complex interactions between their culture and nature that constitutes the biocultural diversity of the WTWHA.

\section{Concluding remarks}

We use this example in the Australian humid tropical rainforests to demonstrate how international heritage designations can empower community efforts to reverse the loss of biocultural diversity. The conditions that enabled empowerment included Rainforest Aboriginal peoples' governance of a heritage nomination process; their 


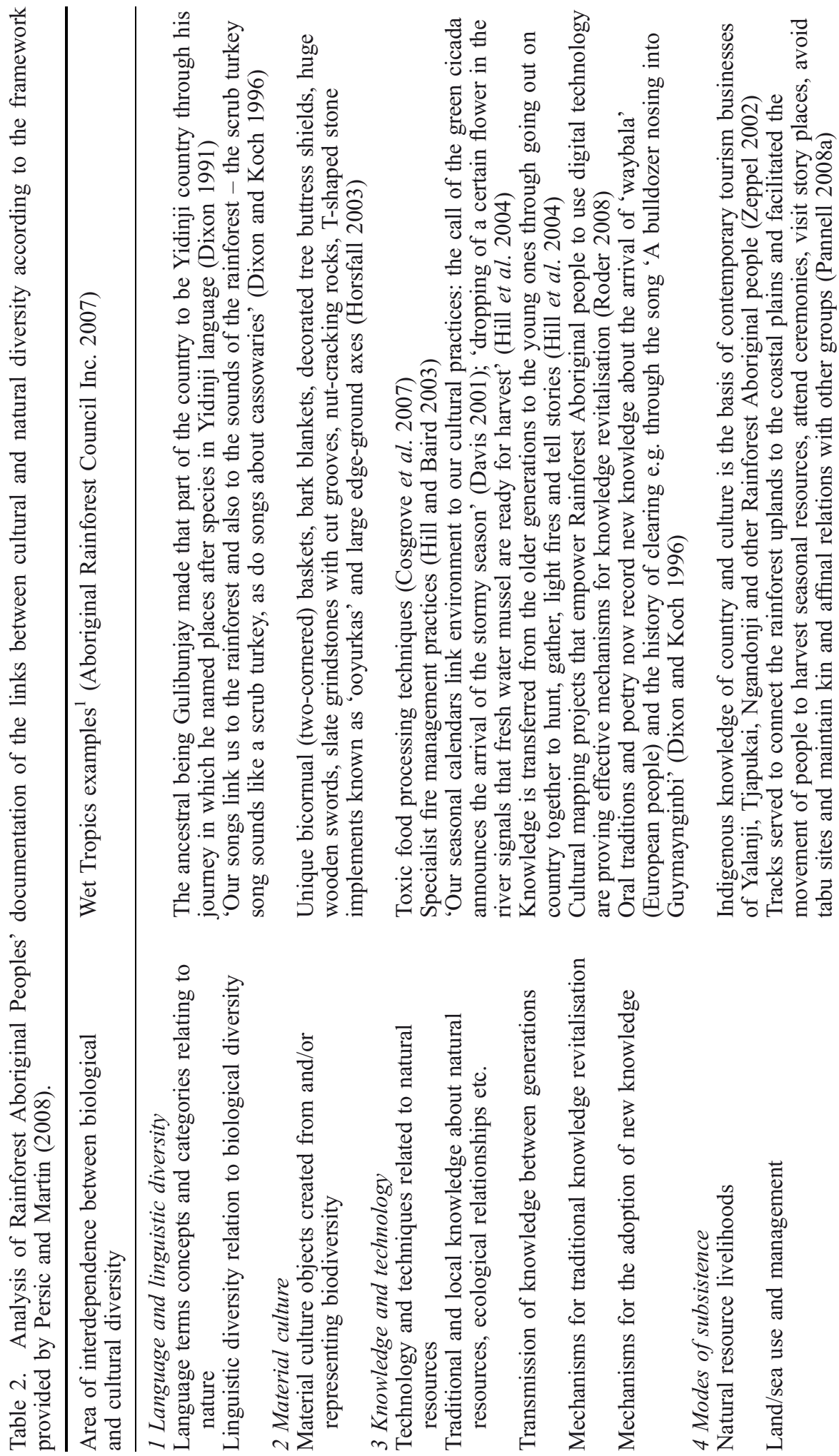




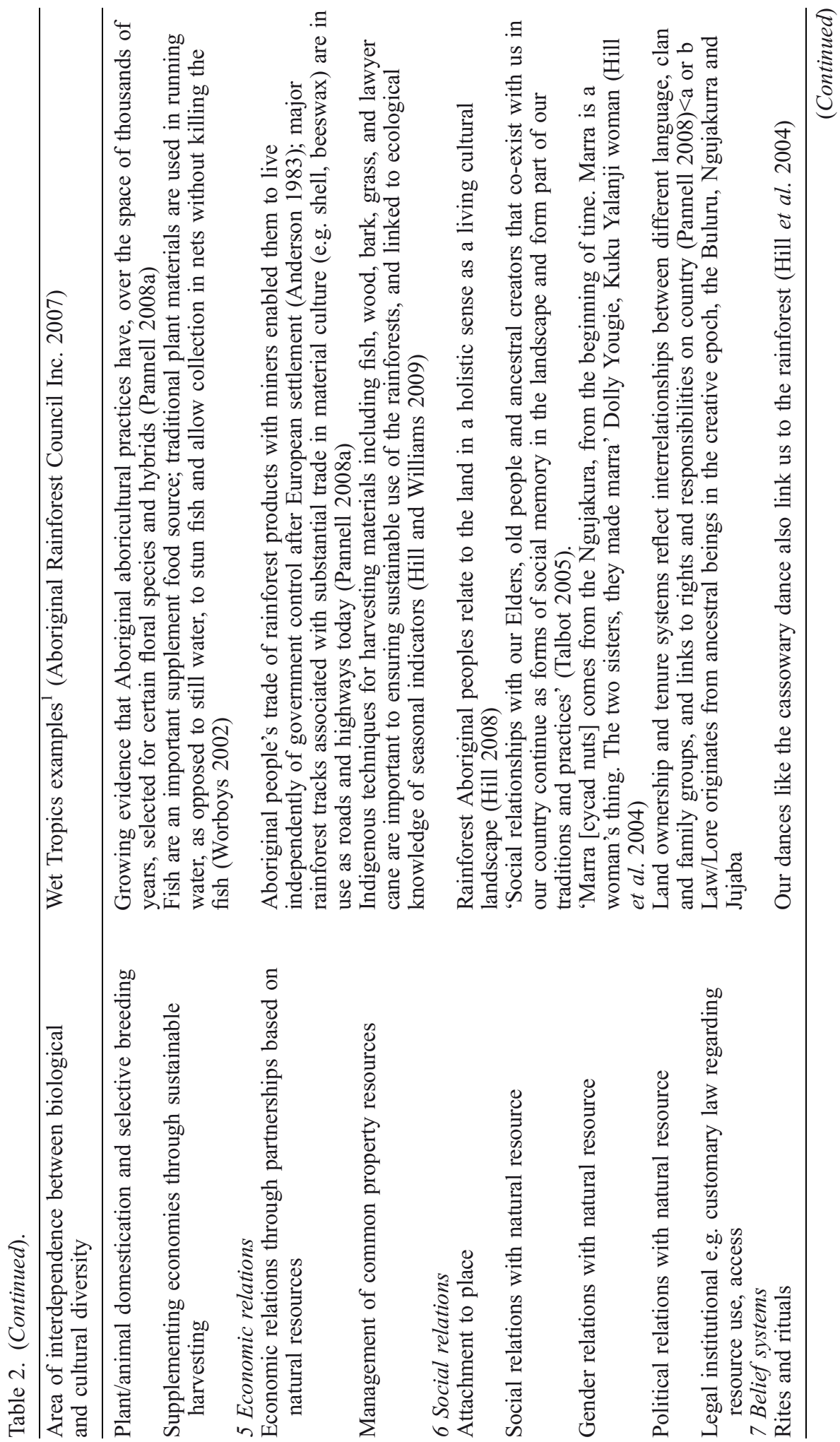


R. Hill et al.

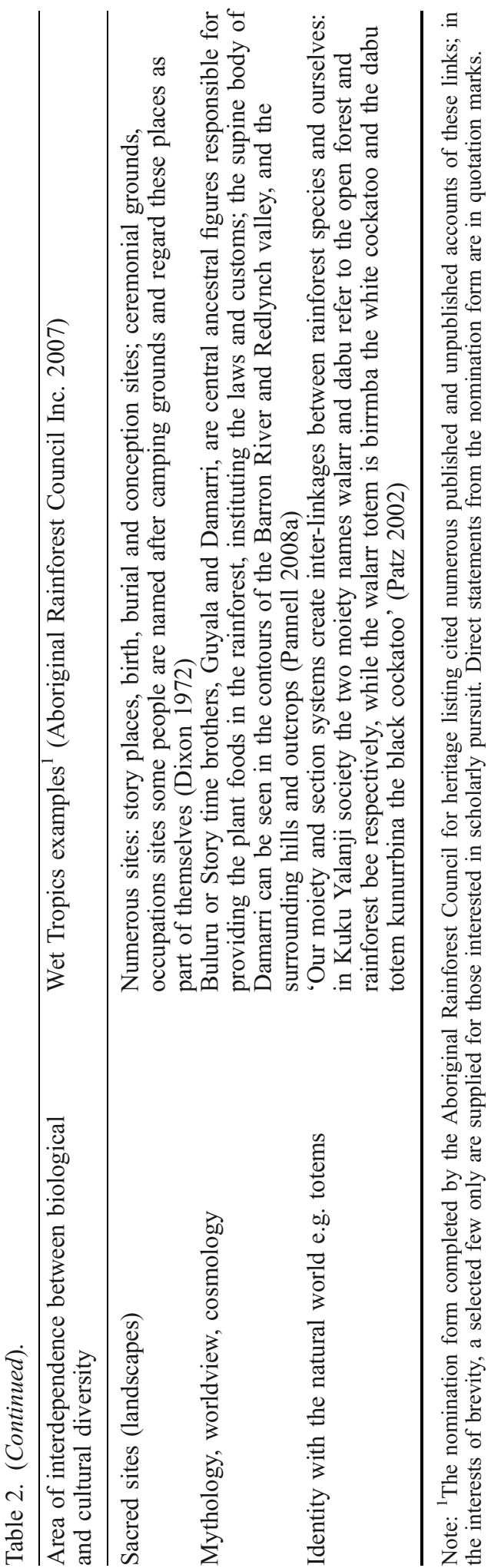


shaping of heritage discourse to incorporate their concept of biocultural diversity; and Indigenous control of interaction with their knowledge systems to identify the links between culture and nature that have created the region's biocultural diversity. The concept of biocultural diversity appears capable of encapsulating the ontological and epistemological differences between Indigenous and other forms of knowledge, recognising the viewpoint that only knowledge that is Indigenous-governed can be Indigenous knowledge (Agrawal 2002). We suggest that the actual reversal of the loss of biocultural diversity in this landscape depends on the delivery of joint management arrangements between the Rainforest Aboriginal People and the Australian nation-state. Joint management based on recognition of rights, cultural values and roles in management, as sought by Rainforest Aboriginal people (Figure 2), will encompass all the elements identified in the international BCP framework as necessary conditions for community empowerment (Persic and Martin 2008; Table 1). Rainforest Aboriginal people in such a joint management partnership could then find the means to renew and strengthen language, fire regimes and the multiple other components of biocultural diversity (Figure 2).

Our co-research confirms the findings by Hemming and Rigney (2010) that Indigenous-driven regional research, planning and development are the means of transforming heritage practices to empower Indigenous peoples. The approach requires collaborative research practices, and significant ongoing work in local, regional, national and international contexts. In the Wet Tropics, Indigenous-driven regional research relied on an organisation to coordinate the governance responsibilities of the 18 TO groups, the Aboriginal Rainforest Council, which as noted earlier no longer exists. While alternative structures for this coordination role are emerging through alliances, Aboriginal people are undertaking this work largely on a voluntary basis, in addition to responsibilities from roles in paid employment. This lack of resources greatly limits their capacity to engage and reflects ongoing marginalisation of Indigenous peoples from funding and support through the Australian NRM arrangements (Hill and Williams 2009). We suggest that national governments need to support Indigenous organisations and their roles in enabling Indigenous knowledge systems for any chance of successful reversal of the loss of biocultural diversity. We commend further investigation of the theory and practice of Indigenous governance as a means to empower community efforts to reverse global biocultural diversity loss.

\section{Acknowledgements}

We thank the Australian Government's Marine and Tropical Science Research Facility, Terrain NRM, CSIRO, the Wet Tropics Management Authority and Rainforest Aboriginal peoples for the support that made this research possible. We particularly acknowledge the invaluable support of Rainforest Aboriginal peoples' organisations including the Aboriginal Rainforest Council, Girringun Aboriginal Corporation and the North Queensland Traditional Owners Water and Land and Management Alliance. Dr Henrietta Marrie provided invaluable guidance as Chair of the ARC Intellectual Property Sub-committee, as did the members, including Ken Reys, Rhonda Brim, Margaret Freeman and Peter Wallace. We would like to acknowledge the fine support of Chantal Roder, Nigel Hedgcock, Linda Leftwich, Steve Turton, Mike Woods and Leigh Pentecost to the project. Liana Williams and Kirsten Maclean provided invaluable comment on earlier versions of this manuscript. We would also like to thank Eastern Kuku Yalanji people for their permission to publish the photographs that accompany this special edition. 


\section{Notes on contributors}

Rosemary Hill is a planning systems scientist with experience in heritage assessment, collaborative planning, research and training with Indigenous communities, Indigenous Land Use Agreements, conservation planning, conservation policy, Aboriginal fire ecology and management, and environmental history.

Leanne C. Cullen-Unsworth is a human ecologist working on sustainability issues in Wales. She previously focused on co-research with Rainforest Aboriginal Peoples in the Wet Tropics to develop linked biophysical and cultural indicators for the WTWHA.

Leah D. Talbot is an Indigenous Environmental Scientist working for a non-governmental environmental organisation, focusing on ways to bring together Indigenous cultural knowledge and natural values of the Cape York Peninsula region.

Susan McIntyre-Tamwoy's research focus includes Indigenous heritage in Cape York Peninsula, climate change, and its impacts on cultural heritage and Indigenous communities. She is currently President of Australia ICOMOS.

\section{Notes}

1. 'Outstanding universal value means cultural and/or natural significance which is so exceptional as to transcend national boundaries and to be of common importance for present and future generations of all humanity' (UNESCO 2008, p. 14).

2. The concept of Indigeneity is highly contested in the academic literature. This article is guided by Martinez-Cobo's (1986, United Nations Permanent Forum on Indigenous Peoples E/CN.4/Sub.2/1986/Add.4) working definition, essentially 'Indigenous communities, peoples and nations are those which, having a historical continuity with pre-invasion and pre-colonial societies that developed on their territories, consider themselves distinct from other sectors of the societies now prevailing on those territories, or parts of them.' In this article, we use the term 'Indigenous' generically to refer to peoples whose origins fit this description, and the word 'Aboriginal' for wet tropics people, according to their own convention.

3. The World Heritage Convention lists places as either natural, cultural, or joint cultural/ natural properties. At the time of listing a cultural landscape was not an available option for the Wet Tropics, and the Australian government chose not to pursue a mixed site.

4. Traditional Owners is the term adopted for Rainforest Aboriginal people who hold rights and interests over land and cultural practices according to traditional law and custom.

\section{References}

Aboriginal Rainforest Council Inc., 2007. Nomination of the Wet Tropics of Queensland World Heritage Area (home of Rainforest Aboriginal People) for inclusion on the National Heritage List. Cairns: Aboriginal Rainforest Council.

Agrawal, A., 2002. Indigenous knowledge and the politics of classification. International Social Science Journal, 54 (173), 287-297.

Anderson, J.C., 1983. Aborigines and tin mining in North Queensland: a case study in the anthropology of contact history. Mankind, 13 (6), 473-498.

Aplin, G., 2007. World Heritage cultural landscapes. International Journal of Heritage Studies, 13 (6), 427-446.

ARC. (Aboriginal Rainforest Council Inc.), 2006. Memorandum of Understanding between the Tropical Landscapes Joint Venture, Terrain Natural Resource Management and Aboriginal Rainforest Council. Cairns: Aboriginal Rainforest Council.

Armitage, D.A., Berkes, F., and Doubleday, N.C., 2007. Introduction: moving beyond Co-management. In: D.A. Armitage, F. Berkes, and N.C. Doubleday, eds. Adaptive co-management collaboration, learning and multi-level governance. Vancouver: UBC Press, $1-15$. 
Berkes, F., 2007. Community-based conservation in a globalized world. Proceedings of the National Academy of Science, 104 (39), 15188-15193.

Bradshaw, C.J.A., Sodhi, N.S., and Brook, B.W., 2009. Tropical turmoil: a biodiversity tragedy in progress. Frontiers in Ecology and the Environment, 7 (2), 79-87.

Chirikure, S., et al., 2010. Unfulfilled promises? Heritage management and community participation at some of Africa's cultural heritage sites. International Journal of Heritage Studies, 16 (1), 30-44.

Cochrane, M., 2003. Building the ARC. Rainforest Aboriginal News, 9, (December), 6-7.

Cocks, M., 2006. Biocultural diversity; moving beyond the realm of 'Indigenous' and 'Local' people. Human Ecology, 34 (2), 185-200.

Cosgrove, R., Field, J., and Ferrier, A., 2007. The archaeology of Australia's tropical rainforest. Palaeogeography, Palaeoclimatology, Palaeoecology, 251, 150-173.

Cullen, L.C., et al., 2008. Framework for the identification of linked cultural and biophysical indicators for the Wet Tropics World Heritage Area. The International Journal of Environmental, Cultural, Economic and Social Sustainability, 4, 37-46.

Davis, G., 2001. The Mullunburra: people of the Mulgrave River. Cairns: Cassowary Publications.

Dixon, R.M.W., 1972. The Dyirbal language of North Queensland. Cambridge: Cambridge University Press.

Dixon, R.M.W., ed., 1991. Words of our country: stories place, names and vocabulary in Yidiny, the Aboriginal language of the Cairns-Yarrabah region. St Lucia: University of Queensland Press.

Dixon, R.M.W. and Koch, G., 1996. Dyirbal song poetry: the oral literature of an Australian Rainforest people. St Lucia: University of Queensland Press.

Folke, C., Hahn, T., Olsson, P., and Norberg, J., 2005. Adaptive governance of socialecological systems. Annual Review of Environment and Resources, 30, 441-473.

Greer, S., 2010. Heritage and empowerment: community-based Indigenous cultural heritage in northern Australia. International Journal of Heritage Studies, 16 (1), 45-58.

Hemming, S. and Rigney, D., 2010. Decentring the new protectors: transforming Aboriginal heritage in South Australia. International Journal of Heritage Studies, 16 (1), 90-106.

Hill, R., 2006. The effectiveness of agreements and protocols to bridge between Indigenous and non-Indigenous tool-boxes for protected area management: a case study from the Wet Tropics of Queensland. Society and Natural Resources, 19 (7), 577-590.

Hill, R., 2008. Linking cultural and natural diversity of global significance to vibrant economies. In: N.E. Stork and S.M. Turton, eds. Living in a dynamic tropical forest landscape. Oxford: Blackwell Publishing, 430-444.

Hill, R. and Baird, A., 2003. Kuku-Yalanji Rainforest Aboriginal people and carbohydrate resource management in the wet tropics of Queensland, Australia. Human Ecology, 30, 27-52.

Hill, R. and Williams, L.J., 2009. Indigenous natural resource management: overcoming marginalisation produced in Australia's current NRM model. In: M.B. Lane, C.J. Robinson, and B.M. Taylor, eds. Contested country: local and regional environmental management in Australia. Canberra: CSIRO Publishing.

Hill, R., et al., 2004. Yalanji-Warranga Kaban. Yalanji people of the Rainforest Fire Management Book. Cairns: Little Ramsay Press.

Hill, R., et al., 2010. Adaptive community-based biodiversity conservation in Australia's tropical rainforest. Environmental Conservation, 37 (1), 73-82.

Horsfall, N., 2003. Aboriginal cultural values of the Wet Tropics Bio-Region: collaborative cultural heritage research report. Cairns: Cooperative Research Centre for Tropical Rainforest Ecology and Management.

Horsfall, H. and Fuary, M., 1988. The cultural heritage values of Aboriginal archaeological sites and associated themes in and adjacent to the area nominated for world heritage listing in the Wet Tropics Rainforest Region of North East Queensland. Unpublished report: A report to the State of Queensland, 12 December. Permit No. 31, EIS. 88.

ICOMOS (International Council on Monuments and Sites), 2009. World Heritage Cultural Landscapes. Paris: UNESCO-ICOMOS Documentation Centre. 
Kato, K., 2006. Community, connection and conservation: intangible cultural values in natural heritage - the case of Shirakami-sanchi World Heritage Area. International Journal of Heritage Studies, 12 (5), 458-473.

Lawson, B., 1998. Review of Aboriginal involvement in the management of the Wet Tropics World Heritage Area. Cairns: Wet Tropics Management Authority.

Leach, M., Mearns, R., and Scoones, I., 1999. Environmental entitlements: dynamics and institutions in community-based natural resource management. World Development, 27 (2), 225-247.

Lennon, J., 2006. Cultural heritage management. In: M. Lockwood, G.L. Worboys, and A. Kothari, eds. Managing protected areas: a global guide. London: Earthscan, 448-473.

Loh, J. and Harmon, D., 2005. A global index of biocultural diversity. Ecological Indicators, 5 (3), 231-241.

Maclean, K. and Cullen, L.C., 2009. Research methodologies for the co-production of knowledge for environmental management. Journal of the Royal Society of New Zealand, 39 (4), 205-208.

Maffi, L., 2005. Linguistic, cultural, and biological diversity. Annual Review of Anthropology, 34, 599-617.

Maffi, L., 2007. Biocultural diversity and sustainability. In: J. Pretty, et al., eds. The Sage handbook of environment and society. London: Sage Publications, 267-275.

Maffi, L. and Woodley, E., eds., 2010. Biocultural diversity conservation: a global sourcebook. London: Earthscan.

Martinez-Cobo, J., 1986. Problem of discrimination against Indigenous populations. London: United Nations Permanent Forum on Indigenous Peoples.

McIntyre-Tamwoy, S., 2004. Social value, the cultural component in natural resource management. Australasian Journal of Environmental Management, 11 (4), 289-299.

Metge, J., 2008. Tumu Te Heuheu (Te Heuheu Tukino VIII). Journal of the Polynesian Society, 117 (1), 7-9.

Pannell, S., 2008a. Aboriginal cultures in the wet tropics. In: N.E. Stork and S.M. Turton, eds. Living in a dynamic tropical forest landscape. Oxford: Blackwell Publishing, 59-70.

Pannell, S., 2008b. 'Getting the mob in': Indigenous initiatives in a new era of natural resource management in Australia. In: N.E. Stork and S.M. Turton, eds. Living in a dynamic tropical forest landscape. Oxford: Blackwell Publishing, 411-419.

Patz, E., 2002. A grammar of the Kuku Yalanji language of North Queensland. Canberra: Pacific Linguistics, Research School of Pacific and Asian Studies, Australian National University.

Persic, A. and Martin, G.J., eds., 2008. Links between biological and cultural diversity concepts, methods and experiences, Report of the 2007 International Workshop. Paris: United Nations Educational Scientific and Cultural Organisation.

Rainforest Aboriginal Network, 1993. Julayinbul Aboriginal intellectual and cultural property: definitions, ownership and strategies for protection in the Wet Tropics World Heritage Area. Daintree: Rainforest Aboriginal Network.

Robinson, G.M., 1998. Methods and techniques in human geography. Chichester: John Wiley \& Sons.

Roder, C., 2008. Cultural heritage mapping project. Rainforest Aboriginal News, 11, 5-6.

Ross, H., et al., 2009. Co-management and Indigenous protected areas in Australia: achievements and ways forward. Australasian Journal of Environmental Management, 16, 51-61.

Rössler, M., 2004. Managing World Heritage cultural landscapes and sacred sites. In: E. de Merode, R. Smeets, and C. Westrik, eds. Linking universal and local values: managing a sustainable future for World Heritage. 13. Paris: UNESCO World Heritage Centre, 45-48.

Rössler, M., 2005. World Heritage cultural landscapes: a global perspective. In: J.R. Brown, N. Mitchell, and M. Beresford, eds. The protected landscape approach linking nature, culture and community. Gland, Switzerland: IUCN, 37-46.

Singh, R.K., Pretty, J., and Pilgrim, S., 2010. Traditional knowledge and biocultural diversity: learning from tribal communities for sustainable development in northeast India. Journal of Environmental Planning and Management, 53 (4), 511-533.

Silverman, H., ed., 2011. Contested cultural heritage: religion, nationalism, erasure and exclusion in a global world. New York: Springer. 
Smith, L., 2007. Empty gestures? Heritage and the politics of recognition. In: H. Silverman and D.F. Ruggles, eds. Cultural heritage and human rights. New York: Springer, 159-171.

Stork, N.E., Goosem, S., and Turton, S.M., 2008. Australian rainforests in a global context. In: N.E. Stork and S.M. Turton, eds. Living in a dynamic tropical forest landscape. Oxford: Blackwell Publishing, 4-20.

Sullivan, S., 2004. Local involvement and traditional practices in the world heritage system. In: E. de Merode, R. Smeets, and C. Westrik, eds. Linking universal and local values: managing a sustainable future for World Heritage. 13. Paris: UNESCO World Heritage Centre, 49-55.

Sveiby, K.E., 2009. Aboriginal principles for sustainable development as told in traditional law stories. Sustainable Development, 17 (6), 341-356.

Talbot, L.D., 2005. Indigenous land management techniques of the Djabugay people. Master's thesis submitted in the School of Tropical Environment Studies and Geography, James Cook University, Cairns.

UNEP, 2009. Bio-cultural community protocols. Creative Commons, South Africa: United Nations Environment Program and Natural Justice.

UNESCO, 2008. Operational guidelines for the implementation of the World Heritage Convention, WHC revised 08/01/2008. Paris: Intergovernmental Committee for the Protection of the World Natural and Cultural Heritage, United Nations Educational, Scientific and Cultural Organisation.

United Nations, 2008. Declaration on the rights of Indigenous peoples. New York: United Nations.

Valentine, P.S. and Hill, R., 2008. The establishment of a World Heritage Area. In: N.E. Stork and S.M. Turton, eds. Living in a dynamic tropical forest landscape. Oxford: Blackwell Publishing, 81-93.

Villalón, A., 2005. World Heritage inscription and challenges to the survival of community life in Philippine cultural landscapes. In: J.R. Brown, N. Mitchell, and M. Beresford, eds. The protected landscape approach linking nature, culture and community. Gland, Switzerland: IUCN, 93-106.

Worboys, P.M., 2002. Ma:Mu and cultural values of plants: an environmental and oral history of culturally important rainforest plants. Honours thesis submitted in the School of Tropical Environment Studies and Geography, James Cook University, Cairns.

WTAPPT, 2005. Caring for country and culture - the Wet Tropics Aboriginal Cultural and Natural Resource Management Plan. Cairns: Wet Tropics Aboriginal Plan Project Team, Rainforest CRC, and FNQ NRM Ltd.

WTRA, 2005. Wet Tropics of Queensland World Heritage Area regional agreement between Rainforest Aboriginal People and the Wet Tropics Management Authority, Queensland Environmental Protection Agency, Queensland Parks and Wildlife Service, Queensland Department of Natural Resources and Mines and The Commonwealth of Australia - the Department of Environment and Heritage - for Management Wet Tropics World Heritage Area. Cairns: Wet Tropics Management Authority, Wet Tropics Regional Agreement.

Zent, S., 2009. Traditional ecological knowledge (TEK) and biocultural diversity: a close-up look at linkages, delearning trends and changing patterns of transmission. In: P. Bates, et al., eds. Learning and knowing in Indigenous societies today. Paris: UNESCO, 39-58.

Zeppel, H., 2002. Indigenous tourism in the Wet Tropics World Heritage Area, North Queensland. Australian Aboriginal Studies, 2, 65-68. 